\title{
Corrigendum
}

\section{Voters, Responsibility Attribution and Support Parties in Parliamentary Democracies - CORRIGENDUM}

\author{
MATHIAS WESSEL TROMBORG, RANDOLPH T. STEVENSON AND \\ DAVID FORTUNATO
}

doi:10.1017/S0007123417000096 Published by Cambridge University Press, 24 August 2017.

The editors apologise for the error in Mathias Tromborg's affiliation in the published paper. The affiliation should be: Department of Political Science, Aarhus University (email: tromborg@ps.au.dk)

\section{REFERENCE}

Tromborg, Mathias, Randolph Stevenson and David Fortunato. Voters, Responsibility Attribution and Support Parties in Parliamentary Democracies. Brit J Polit Sci. Published by Cambridge University Press, 24 August 2017. doi: 10.1017/S0007123417000096. 